\title{
Preliminar Evaluation of Performance in Topcrosses Between Vegetable Type and Grain Type Soybean
}

\author{
Gilberto K. Yokomizo ${ }^{* 1}$, Natal A. Vello ${ }^{2}$ and Marcos C. Nekastchalow ${ }^{2}$ \\ ${ }^{I}$ Embrapa Amapá, Rod. Juscelino Kubitschek, $k m$ 05, Caixa Postal 10, CEP 68902-280, Macapá-AP, Brazil \\ ${ }^{2}$ Departamento de Genética - ESALQ/USP, Caixa Postal 83, CEP 13400-970, Piracicaba-SP, Brazil
}

\begin{abstract}
Studies were conducted to evaluate the performance of topcrosses between food type soybean (with tendency to low physiological quality of the seeds) with two adapted grain type, seeking to associate adequate human food characteristics with adaptability. The conclusions were: a) The best topcrosses for vegetable type soybean were obtained predominantly with 'FT-2' and for seed yield with 'Doko'; b) The evaluated topcrosses presented high sensibility to winter conditions in comparison to summer, consequently the selection process in the winter it must be avoided; c) The selection for food type soybean it must be established in adequate values between individual plant yield and one hundred seed weight.
\end{abstract}

Key words: Glycine max, seed size, vegetal breeding, vegetal germplasm

\section{INTRODUCTION}

The soybean has a significant economic importance for Brazil, with production estimated in 30 million tons of grains (Agrianual, 1998), behind only of the corn.

Exist a soybean classification in two groups in agreement with its principal uses: the first group, denominated grain type is employed manly in the bran and oil production, with medium grain size (one hundred seed weight (HSW) varying among 10 to $19 \mathrm{~g}$ ), however has undesirable flavor; the second group is denominated food type, with flavor taste, constituted by two subgroups, the first with HSW smaller than $10 \mathrm{~g}$, consumed in the sprouts form and natto (fermented) and the second with HSW presenting $20 \mathrm{~g}$ or more, being consumed directly by human principally in the snack form, and denominated vegetable soybean, green soybean or edamame (Vello, 1992).

The food type soybean consumption is common in oriental countries and very low in occidental countries, because the following peculiarities: a) very rigid alimentary habit, the occidental people not accept menu alterations easily; b) inadequate flavor for occidental taste; c) the soybean brain or grain is employed mainly for animal nutrition; d) absence of a adequate marketing program about soybean qualities in human alimentation from government.

Adequate balance between the nutricional values and protein content is a important characteristic in soybean, which is superior than the bovine meat, cow milk and eggs, this protein could heal the malnutrition from peoples in substitution at the animal protein (Carrão-Panizzi, 1988), with smaller production expenses (Canto \& Turatti, 1989).

The main characteristics presented by the vegetable soybean are big seeds; sweetened flavor (similar to the nuts); without or smaller undesirable smell (Rackis et al., 1979) and smaller anti-nutritional factors content, principally the Bowmann Birk and Kunitz anti proteases (Orf, 1989), this characters are found in Japanese and Chinese genotypes. This genotypes exhibit very precocious flowering and many has determined growth habit, this association is responsible for grain production diminution when cultivated in low latitudes (Santos, 1988). A solution adopted to solve this problem in the soybean's improvement program from Department of Genetics of the ESALQ/USP was the crossing of the exotic food type genotypes with grain type

\footnotetext{
* Author for correspondence
} 
adapted, combining favorable genes of the human consumption (from exotic) with adaptability and better physiologic quality to seeds (from adapted). The work objectives were evaluate in a preliminary study the performance of the topcrosses between food type with grain type soybeans based in the characters: plant height at maturity, grain size and yield. The grain yield is important because the possibility to employ the selected material to amplification of the genetic base in the grain type soybean germplasm from Brazil, besides comparing the best performance from topcrosses of the $\mathrm{F}_{5: 4}$ generation with the previous ones. The other objective was to identify the better genotypes (topcrosses) for vegetable type soybean characteristics.

\section{MATERIAL AND METHODS}

The study was conducted in experimental area of Genetic Department, ESALQ/USP, in Piracicaba City, São Paulo State, on a soil classified as alfisol type. The season year was 1991/1992.

The evaluated genotypes were 67 topcrosses from $\mathrm{F}_{5: 4}$ generation, obtained by crossing between 41 vegetable type with 2 males adapted grain type soybean (Doko and FT-2). The male's genotypes were selected because the high physiological quality from seeds.

The experimental design employed was the randomized block with 6 repetitions and 12 plants for repetition, with 72 plants in the total for each topcross and four checks (IAC Santa Maria 702, Céu Azul, Stwart and IAC PL-1). Each experimental plot was composed by three rows with four plants (hills) in each row, with an average distance of $0.5 \mathrm{~m}$ between plants and 0.5 $m$ between rows.

The evaluated characters were:

PHM: plant height at maturation, in $\mathrm{cm}$, measured as the distance between the soil and the inflorescence insertion most distant from main stem, analyzed on $\mathrm{R}_{8}$ stage;

PWV: pod width by visual score, applied in the middle of distal locus, note based in scale from 1 (it narrows) until 5 (it releases), analyzed on $\mathrm{R}_{8}$ stage;

IPY: individual plant yield, in grams, evaluated after pod threshing of individual plants;
HSW: one hundred seed weight, in grams, calculated taking the weight of 100 seeds per individual plant.

Averages were calculated for each topcross, each check and for general checks average, the observed progress for each topcross (OP) in percentage in relation at the general checks average was obtained by equation:

$$
\mathrm{OP}_{\mathrm{i}}=\left(\frac{\mathrm{AT}_{\mathrm{i}}}{\mathrm{AC}}-1\right) \times 100
$$

$\mathrm{OP}_{\mathrm{i}}$ : observed progress in percentage by i-esime topcross $(\mathrm{i}=1, \ldots, 67)$;

$\mathrm{AT}_{\mathrm{i}}$ : average of the $\mathrm{i}$-esime topcross $(\mathrm{i}=1, \ldots, 67)$;

$\mathrm{AC}$ : general checks average.

\section{RESULTS AND DISCUSSION}

Only four topcrosses in the $\mathrm{F}_{5: 4}$ generation showed higher averages for plant height at maturation (PHM) in comparison to the general average of checks (Table 1), and everybody was obtained with 'Doko' parental. The topcrosses averages involving the 'FT-2' parental were smaller than topcrosses with 'Doko' parental, for this reason none 'FT-2' topcross was selected. However, is important to emphasize the existence of progenies inside topcrosses with PHM adequate for cultivation, but in the present experiment didn't satisfactory performance, but perhaps in other environments exhibit adequate PHM. Without doubt, none topcross to be discarded, but yes, also evaluated carefully in relation to the other important characters for vegetable type.

Observed progress in percentage (OP) for PHM from superior topcrosses varied at 4 to $25 \%$ (Table $1)$, results that are to fit in a strip supposedly appropriate, because above those OP values the plant can lodge in an undesirable manner, and down those values the mechanized harvest is prejudiced.

The averages obtained to PHM (Table 1) from $\mathrm{F}_{5: 4}$ generation were very superior in relation at the obtained by Destro (1991) from $\mathrm{F}_{2}$ generation and from $F_{3}$ generation by Pacova (1992), due evaluation from $F_{2}$ and $F_{3}$ generation has been in winter epoch and the generation $\mathrm{F}_{5: 4}$ in the summer. The distinct performances observed in different epochs to make easy discern that exist a strong environmental influence contributing to this character. Therefore, isn't recommended to plant the topcrosses evaluated in the winter, because the 
development for PHM character can be prejudiced

Destro, 1991).

$(40 \mathrm{~cm}$ from maximum averages obtained for

Table 1 - PHM: plant height at maturity $(\mathrm{cm})$. Superior crossings averages in relation to general checks average from $\mathrm{F}_{5: 4}$ generation; average from $\mathrm{F}_{2}$ and $\mathrm{F}_{3}$ generations; average for each check; general checks average; OP: observed progress in relation to general checks average.

\begin{tabular}{|c|c|c|c|c|c|c|}
\hline Genotypes & & & average from $\mathrm{F}_{2}$ & average from $\mathrm{F}_{3}$ & average from $\mathrm{F}_{5: 4}$ & $\mathrm{OP}$ \\
\hline \multicolumn{7}{|l|}{ Crossings: } \\
\hline Araçatuba & $\mathrm{x}$ & Doko & 48 & 74 & 106 & 25 \\
\hline IAC Sta. Maria 702 & $\mathrm{x}$ & Doko & 38 & 81 & 103 & 21 \\
\hline Stwart & $\mathrm{x}$ & Doko & 47 & 72 & 96 & 13 \\
\hline Biloxi 252N & $\mathrm{x}$ & Doko & 45 & 78 & 88 & 4 \\
\hline \multicolumn{7}{|l|}{ Checks: } \\
\hline & \multicolumn{3}{|c|}{117} \\
\hline \multirow{2}{*}{\multicolumn{4}{|c|}{$\begin{array}{l}\text { Stwart } \\
\text { Ceu Azul }\end{array}$}} & \multicolumn{3}{|c|}{87} \\
\hline & & & & \multirow{2}{*}{\multicolumn{3}{|c|}{$\begin{array}{l}65 \\
73\end{array}$}} \\
\hline \multicolumn{4}{|l|}{ IAC PL-1 } & & & \\
\hline \multicolumn{4}{|c|}{ General checks average } & \multicolumn{3}{|c|}{85} \\
\hline
\end{tabular}

Table 2 - PWV: pod width by visual score (score from 1 to 5). Superior crossings averages in relation to general checks average from $\mathrm{F}_{5: 4}$ generation; average from $\mathrm{F}_{3}$ generation; average for each check; general checks average; OP: observed progress in relation to general checks average.

\begin{tabular}{|c|c|c|c|c|c|}
\hline Genotypes & & & average from $\mathrm{F}_{3}$ & average from $\mathrm{F}_{5: 4}$ & $\mathrm{OP}$ \\
\hline \multicolumn{6}{|l|}{ Crossings: } \\
\hline Yamagataken & $\mathrm{x}$ & FT-2 & 2,2 & 3,8 & 27 \\
\hline Miyashipoken & $\mathrm{x}$ & FT-2 & 2,2 & 3,8 & 27 \\
\hline Late Giant & $\mathrm{x}$ & FT-2 & 2,1 & 3,7 & 23 \\
\hline Japão 1 & $\mathrm{x}$ & Doko & 2,3 & 3,6 & 20 \\
\hline Japão 1 & $\mathrm{x}$ & FT-2 & 2,5 & 3,5 & 17 \\
\hline PI 80441 & $\mathrm{x}$ & FT-2 & 2,1 & 3,4 & 13 \\
\hline Tadacha & $\mathrm{x}$ & Doko & 2,0 & 3,4 & 13 \\
\hline Hakucho & $\mathrm{x}$ & FT-2 & 1,9 & 3,4 & 13 \\
\hline PI 230977-sel & $\mathrm{x}$ & FT-2 & 2,1 & 3,3 & 10 \\
\hline Pl 230977 & $\mathrm{x}$ & FT-2 & 2,0 & 3,3 & 10 \\
\hline Aliança Preta & $\mathrm{x}$ & Doko & 2,1 & 3,3 & 10 \\
\hline PI229343 & $\mathrm{x}$ & FT-2 & 2,1 & 3,3 & 10 \\
\hline TK\#5 x Unknown F7 & $\mathrm{x}$ & FT-2 & 2,4 & 3,3 & 10 \\
\hline Kurakake & $\mathrm{x}$ & Doko & 2,2 & 3,3 & 10 \\
\hline Nimame & $\mathrm{x}$ & FT-2 & 2,2 & 3,2 & 7 \\
\hline Miyashipoken & $\mathrm{x}$ & Doko & 2,1 & 3,2 & 7 \\
\hline PI 165676 & $\mathrm{x}$ & FT-2 & 2,1 & 3,2 & 7 \\
\hline Japão 2 & $\mathrm{x}$ & FT-2 & 2,3 & 3,2 & 7 \\
\hline TK\#5 x Unknown F7 & $\mathrm{x}$ & Doko & 2,0 & 3,2 & 7 \\
\hline Tarheel Black & $\mathrm{x}$ & FT-2 & 2,0 & 3,1 & 3 \\
\hline PI 229343 & $\mathrm{x}$ & Doko & 2,0 & 3,1 & 3 \\
\hline Late Giant & $\mathrm{x}$ & Doko & 2,0 & 3,1 & 3 \\
\hline Japão 2 & $\mathrm{x}$ & Doko & 2,1 & 3,1 & 3 \\
\hline
\end{tabular}


Checks:

IAC Sta. Maria $702 \quad 1,5$

$\begin{array}{lr}\text { Stwart } & 2,6\end{array}$

Се́u Azul $\quad 3,2$

IAC PL-1 3,3

General checks average* $\quad 3,0$

* average among 3 checks with larger seeds

For the PWV character (Table 2) 23 topcrosses showed larger averages than the general checks average, this number represent $30 \%$ of the 67 topcrosses evaluated, indicating a number relatively high with pods dimension interesting, appropriated for classification in vegetable type soybean. The PWV average varied from 3,1 to 3,8 for superior topcrosses, with estimated OP between $3 \%$ and $27 \%$, and the three best topcrosses were obtained with 'FT-2'. In relation to average of the best check (PL-1 with average from 3,3 ), eight superior topcrosses were obtained, being six with 'FT-2' and two with 'Doko', indicating a tendency of topcrosses with 'FT-2 to possess wider pods in relation at the topcrosses with 'Doko'. This fact occurred how result from larger seeds from 'FT-2' parental compared with 'Doko' parental, and apparently there was tendency of the seed size from parental to be inherited by topcrosses.

Overall, the PWV performance (Table 2) was superior in the $F_{5: 4}$ generation in relation to $F_{3}$ (Pacova, 1992) indicating the best development in the summer season, however, occurred correspondence of the best topcrosses among generations. In the Table 2 is possible to visualize the prejudicial influence of winter conditions in the pods development $\left(\mathrm{F}_{3}\right.$ generation), in which the PWV averages were smaller in comparison with $\mathrm{F}_{5: 4}$ generation.

For the HSW character (Table 3) 26 topcrosses were superior in relation to general checks average, coincidentally 21 from these were also obtained for PWV, indicating a high correlation between HSW and PWV, these results agree with those obtained by Lopes et al. (1997) and Yokomizo \& Vello (1998). The five best topcrosses for HSW were obtained with 'FT-2' and in relation at the 26 topcrosses with positives OP, 15 were obtained with 'FT-2' and 11 with 'Doko`. Confirming that the 'FT-2 ' parental has larger seed than 'Doko' parental and in general the topcrosses inherited the character. The OP showed values from $4 \%$ to $25 \%$ in relation to general checks average for HSW, those values possibility the topcrosses selection with averages above 25 $\mathrm{g} / 100$ seeds, it means were $5 \mathrm{~g}$ above the minimum necessary for selection as vegetable soybean, existing other topcrosses with HSW averages for it be fitted in the category of vegetable soybean, but in the environmental conditions for $\mathrm{F}_{5: 4}$ generation was not selected.

Comparison between the results obtained among the $F_{2}$ (Destro, 1991), $F_{3}$ (Pacova, 1992) and $F_{5: 4}$ generations (Table 3) showed that in the winter generations $\left(F_{2}\right.$ and $\left.F_{3}\right)$ the averages for topcrosses are very similar, while in summer conditions $\left(\mathrm{F}_{5: 4}\right.$ generation) the average had a considerable increment, fact that can have been influenced for differences in the photosynthetic rate, hydric conditions, sunstroke and temperature.

Table 3 - HSW: one hundred seed weight (g/100 seeds). Superior crossings averages in relation to general checks average from generation $\mathrm{F}_{5: 4}$; averages from $\mathrm{F}_{2}$ and $\mathrm{F}_{3}$ generations; average for each check; general checks average; OP: observed progress in relation to general checks average. 


\begin{tabular}{|c|c|c|c|c|c|c|}
\hline Genotypes & & & average from $\mathrm{F}_{2}$ & average from $\mathrm{F}_{3}$ & average from $\mathrm{F}_{5: 4}$ & $\mathrm{OP}$ \\
\hline \multicolumn{7}{|l|}{ Crossings: } \\
\hline Yamagataken & $\mathrm{x}$ & FT-2 & 21 & 21 & 30 & 25 \\
\hline Japão 2 & $\mathrm{x}$ & FT-2 & 21 & 22 & 29 & 21 \\
\hline Miyashipoken & $\mathrm{x}$ & FT-2 & 22 & 21 & 29 & 21 \\
\hline Japão 1 & $\mathrm{x}$ & FT-2 & 22 & 24 & 28 & 17 \\
\hline PI 229343 & $\mathrm{x}$ & FT-2 & 22 & 22 & 28 & 17 \\
\hline Japão 1 & $\mathrm{x}$ & Doko & 22 & 22 & 28 & 17 \\
\hline PI 80441 & $\mathrm{x}$ & FT-2 & 19 & 20 & 28 & 17 \\
\hline Kurakake & $\mathrm{x}$ & Doko & 22 & 22 & 28 & 17 \\
\hline Japão 2 & $\mathrm{x}$ & Doko & 22 & 22 & 27 & 13 \\
\hline Late Giant & $\mathrm{x}$ & FT-2 & 24 & 23 & 27 & 13 \\
\hline Nimame & $\mathrm{x}$ & FT-2 & 23 & 23 & 26 & 8 \\
\hline PI 230977 & $\mathrm{x}$ & FT-2 & 21 & 21 & 26 & 8 \\
\hline PI 229343 & $\mathrm{x}$ & Doko & 22 & 20 & 26 & 8 \\
\hline Late Giant & $\mathrm{x}$ & Doko & 23 & 22 & 26 & 8 \\
\hline Yamagataken & $\mathrm{x}$ & Doko & 22 & 21 & 26 & 8 \\
\hline Hakucho & $\mathrm{x}$ & Doko & 21 & 17 & 25 & 4 \\
\hline Tadacha & $\mathrm{x}$ & Doko & 22 & 22 & 25 & 4 \\
\hline PI 80441 & $\mathrm{x}$ & Doko & 21 & 20 & 25 & 4 \\
\hline PI 243514 & $\mathrm{x}$ & FT-2 & 23 & 20 & 25 & 4 \\
\hline PI 230977-sel & $\mathrm{x}$ & FT-2 & 23 & 22 & 25 & 4 \\
\hline PI 165676 & $\mathrm{x}$ & FT-2 & 21 & 21 & 25 & 4 \\
\hline Hakucho & $\mathrm{x}$ & FT-2 & 21 & 17 & 25 & 4 \\
\hline Tarheel Black & $\mathrm{x}$ & FT-2 & 22 & 20 & 25 & 4 \\
\hline PI 230977 & $\mathrm{x}$ & Doko & 22 & 20 & 25 & 4 \\
\hline TK\#5 x Unknown F7 & $\mathrm{x}$ & FT-2 & 21 & 21 & 25 & 4 \\
\hline Aliança Preta & $\mathrm{x}$ & Doko & 23 & 22 & 25 & 4 \\
\hline
\end{tabular}

\section{Checks:}

\begin{tabular}{lc} 
IAC Sta. Maria 702 & 11 \\
Stwart & 20 \\
Céu Azul & 26 \\
IAC PL-1 & 25 \\
& \\
General checks average * & 24 \\
\hline
\end{tabular}

* average among 3 checks with larger seeds

For the character IPY (Table 4), only seven topcrosses showed superior averages in relation at the general checks average, what confirms that the exotic materials are really of low yield in our conditions, this results agree with those obtained by Guerra et al. (1999). However these 72 evaluated topcrosses would have usefulness for the amplification of the genetic base from grain type soybean present in Brazil. The OP values for the best topcrosses varied from 2 until $50 \%$, and six of these superior topcrosses were obtained with 'Doko' and only one with 'FT-2', distinction to the topcross PI 91725-3 x Doko with production $50 \%$ above than general checks average.

Observing the seed yield (Table 4) in the winter conditions $\left(\mathrm{F}_{2}\right.$ and $\mathrm{F}_{3}$ generations) in relation at the summer $\left(\mathrm{F}_{5: 4}\right.$ generation $)$ a significant difference can be noted, where the best medium results were obtained in the generation cultivated in the summer.

Table 4 - IPY: individual plant yield (g/plant). Superior crossings averages in relation to general checks average from $\mathrm{F}_{5: 4}$ generation; average from $\mathrm{F}_{2}$ and $\mathrm{F}_{3}$ generations; average for each check; general checks average; OP: observed progress in relation to general checks average.

\begin{tabular}{lllll}
\hline Genotypes & average from $\mathrm{F}_{2}$ & average from $\mathrm{F}_{3}$ & average from $\mathrm{F}_{5: 4}$ & OP \\
\hline
\end{tabular}




\section{Crossings:}

\begin{tabular}{|c|c|c|c|c|c|c|}
\hline PI $91725-3$ & $\mathrm{x}$ & Doko & 36 & 49 & 72 & 50 \\
\hline Majós & $\mathrm{x}$ & Doko & 23 & 43 & 58 & 21 \\
\hline Aliança Preta & $\mathrm{x}$ & Doko & 34 & 43 & 54 & 13 \\
\hline Stwart & $\mathrm{x}$ & Doko & 35 & 42 & 53 & 10 \\
\hline Araçatuba & $\mathrm{x}$ & FT-2 & 26 & 31 & 52 & 8 \\
\hline Hogyoku & $\mathrm{x}$ & Doko & 24 & 38 & 50 & 4 \\
\hline IAC Sta, Maria 702 & $\mathrm{x}$ & Doko & 35 & 41 & 49 & 2 \\
\hline \multicolumn{7}{|l|}{ Checks: } \\
\hline IAC Sta. Maria 702 & & & & & 44 & \\
\hline Stwart & & & & & 51 & \\
\hline Се́u Azul & & & & & 51 & \\
\hline$I A C P L-1$ & & & & & 44 & \\
\hline General checks average & & & & & 48 & \\
\hline
\end{tabular}

Is important remember that a careful seed yield evaluation is necessary, because the best topcrosses for HSW character also may to exhibit satisfactory IPY, being not necessary that are the most productive, consequently, a balance between HSW and IPY is need to adequated selection for food type soybean.

\section{CONCLUSIONS}

The best topcrosses for vegetable type soybean were obtained predominantly with 'FT-2' parental and for seed yield with 'Doko' parental.

The evaluated topcrosses presented high sensibility in winter conditions when in comparison at the summer season, then the selection process in the winter seasons it must be avoided.

The selection for vegetable type soybean it must be established in adequate values between IPY and HSW, avoiding to selection process based only at one character.

\section{ACKNOWLEDGE}

To CNPq for the financing of the research.

\section{RESUMO}

A soja hortaliça, com sabor agradável, sementes grandes, destinada ao consumo humano direto, apresenta sementes com baixa qualidade fisiológica e alta sensibilidade ao fotoperíodo, sendo que para corrigir estes problemas foram realizados topocruzamentos entre soja tipo alimento com dois tipo grão adaptados, procurando associar características adequadas para alimento humano com adaptabilidade. As conclusões obtidas para estes topocruzamentos foram: a) Os melhores topocruzamentos para tipo hortaliça foram obtidos predominantemente com 'FT-2` e para produtividade de grãos com 'Doko'; b) Os topocruzamentos avaliados apresentaram alta sensibilidade as condições de inverno em comparação as de verão, com isto o processo de seleção no inverno deve ser evitado; c) A seleção para soja tipo hortaliça deve ser estabelecida em valores adequados entre a produtividade por planta individual e peso de cem sementes, evitando o processo de seleção baseado em somente um caráter.

\section{REFERENCES}

AGRIANUAL (1998) Anuário da Agricultura Brasileira. São Paulo: FNP Consultoria \& Comércio. p.355-388. 
Canto, W. L. ; Turatii, J. M. Produção e mercado de produtos intermediários protéicos de soja no Brasil. Boletim CEPPA, 7 (2), p.111-139, 1989.

Carrão-Panizzi, M. C. Valor nutritivo da soja e potencial de utilização na dieta brasileira. Londrina: EMBRAPA / CNPSo, 1988. 13p. (Documentos, 29).

Destro, D. Capacidade de combinação de genótipos de soja [Glycine max (L.) Merrill] apropriados para o consumo humano. Piracicaba, 1991. 158p. Tese(Doutorado)-Escola Superior de Agricultura "Luiz de Queiroz", Universidade de São Paulo.

Guerra, E.P.; Destro, D.; Miranda, L.A.; Montalván, R. Performance of food-type genotypes and their possibility for adaptation to brazilian latitudes. Pesquisa Agropecuária Brasileira, 34 (4), p.575-583, 1999.

Lopes, E.C.A.; Destro, D.; Montalván, R.; Ventura, M.V.; Guerra, E.P. Genetic gain and correlations among traits for stink bug resistance in soybeans. Euphytica, 97 p.161-166, 1997.

Orf, J. H. Breeding soybeans lacking antinutritional factors. In: WORLD SOYBEAN RESEARCH CONFERENCE, 4., Buenos Aires, 1989. Proceedings. Buenos Aires: Associacion Argentina de la Soja, 1989. p.1091-1100.

Pacova, B. E. V. Análise genética de progênies segregantes de soja apropriada para o consumo humano. Piracicaba, 1992. 217 p. Tese(Doutorado)-
Escola Superior de Agricultura "Luiz de Queiroz", Universidade de São Paulo.

Rackis, J. J.; Sessa, D. J.; Honig, D. H. Flavor problems of vegetable food proteins. Journal of the American Oil Chemists Society, 56 (3), p.262-271, 1979.

Santos, A. L. C. Variabilidade entre genótipos de soja (Glycine $\max (\mathrm{L}$.$) Merrill) nas fases imatura e madura$ de desenvolvimento. Piracicaba, 1988. 135 p. Dissertação(Mestrado)-Escola Superior de Agricultura "Luiz de Queiroz", Universidade de São Paulo.

Vello, N. A. Ampliação da base genética do germoplasma e melhoramento da soja na ESALQUSP. In: Câmara, G. M. S.; Marcos Filho, J.; Oliveira, E. A. M., (Ed.) Simpósio sobre cultura e produtividade da soja. Piracicaba: FEALQ, 1992. p.60-81

Yokomizo, G.K.; Vello, N.A. Use of pod width as visual score in substitution of one hundred seed weight on vegetable soybean. Soybean Genetics Newsletter, 25, p.21-22, 1998.
Received: June 08, 1999;

Revised: July 27, 1999; Accepted: October 28, 1999. 